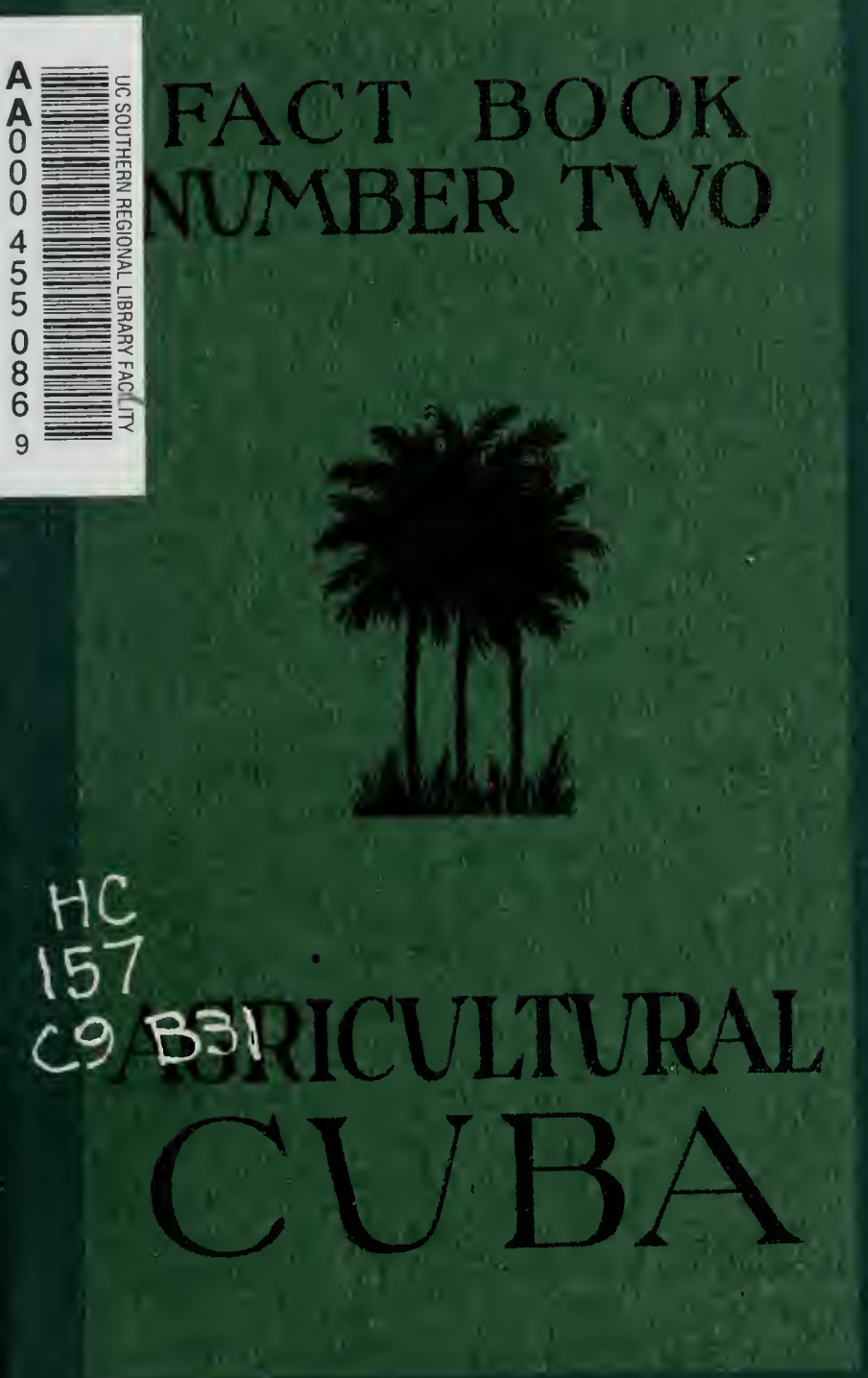



<smiles>CCCCCCC(C)C</smiles> 
Digitized by the Internet Archive in 2008 with funding from Microsoft Corporation 


\section{AGRICULTURAL CUBA}

Condensed Facts Regarding the Products and Possibilities of Agricultural

Development of the

Republic.

$\underline{\text { Including }}$

Statistics and Data of

Reference 
Copyright I9I 6

by the

Bankers' Loan \& Securities Company

New Orleans

Louisiana

U. S. A. 


\section{AGRICULTURAL CUBA}

THE Cuban Department of Agriculture, Commerce and Labor while under the direction of a member of the National Cabinet, is sub-divided into three distinct departments for purposes of efficiency. One section supervises the sugar and tobacco plantations, maintains an agronomic station and experimental farm and publishes an official bulletin along educational lines. This department has in charge agricultural colonization, the official cattle register and the meteorological service.

The second section has in charge all matters pertaining to Mines, Forests, Banks, Mercantile Establishments and Corporations. The Copyright, Trade-mark and Patent Offices, as well as the Bureau of Weights and Measures and the Bureau of Labor and Colonization and in short all matters relating to the promotion and regulation of Commerce and Industry come under the control of this section.

A third section regulates hunting, fishing, the protection of birds and deals with the protection against pests.

In this work we deal more particularly with agricultural products as they are known in the United States, instead of attempting to cover the varying duties of the Department as a whole.

At first glance it would appear that this department is too broad in its scope but when we realize that the Republic of Cuba in area is about the same size as our Pennsylvania, the reason for grouping these departments will be apparent. 


\section{SUGAR THE LEADING CROP}

'The production of cane sugar represents seventyseven per cent of the agriculture of Cuba. Climate and soil make Cuba the natural sugar growing country of the world and a reading of the following will demonstrate the importance of this crop in international commerce.

\section{AVERAGE PRODUCTIVITY}

An acre of ground in Cuba ordinarily produces about ten (IO) sacks, but the average for the Island is about twelve sacks, since considerable of the new land will produce far more than the average. Twelve sacks per acre represents 3900 lbs. of sugar, each sack weighing thirteen arrobas of twenty-five pounds each, or a total of 325 pounds per sack. Thus, even under minimum conditions, a sack of sugar is worth approximately $\$ 8.50$. If the grower plants on land belonging to the mill his share is from forty-five to fifty per cent on the "first" sugar, that is, the firstgrade sugar. 'This is about four and one-half or five per cent of the weight of the cane, and at twelve sacks to the acre will amount to from $\$ 45.90$ to $\$ 51.00$ per acre. If the owner plants on his own land, he receives from fifty-five to sixty per cent of the first-grade sugar, or approximately five and one-half to six per cent of the weight of his cane in sugar, which would amount to from $\$ 56.00$ to $\$ 6 \mathrm{I} .00$ per acre; the remainder going to the mill. 'The mill receives the benefit of all second grade sugar, which is from one and one-half to two sates of sugar to the acre. It also receives all of the molasses. 
Sugar cane is a crop to count upon and it is one that does not require the care and delicate attention necessary for the production of tobacco and other sensitive crops. To those of limited circumstances, cane offers great opportunities since the mills make liberal allowances in advances to the growers, furnishing them with oxen, implements and provisions necessary to carry them through the (crop) season. The production of cane does not require a great amount of skill. The plowing for Spring planting is done in January, February and March, and planting in April and May. Fall planting is done in August and as late as September, sometimes. 


\section{CUBA'S CANE SUGAR PRODUCTION}

According to Mr. H. A. Himely, Sugar Statistician, Cuba has produced the greater portion of the world's sugar supply since I854, as shown by the following figures:

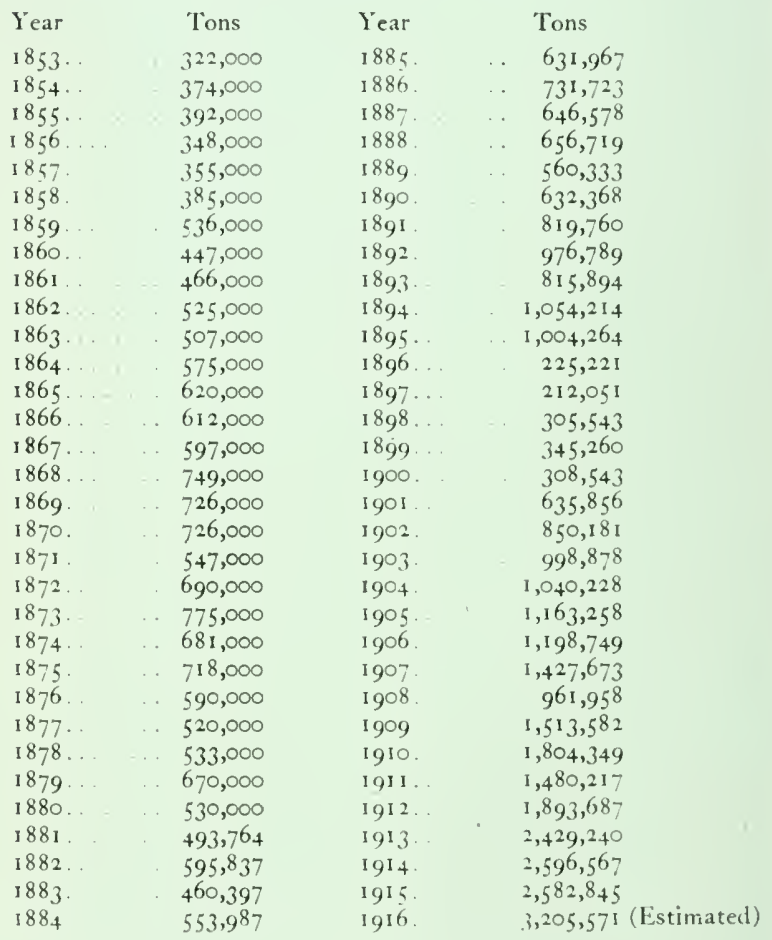


It will be noted that there has been a general increase in production since 1897 , when 212,000 tons were produced, as against $3,000,000$ tons, estimated, in 1916.

'The value of Cuba's sugar crop forms an accurate index to her commercial prosperity. :The average annual value for some years past has been in the neighborhood of $\$ 165,000,000.00$. The first year of the European War raised this figure to $\$ 204,000,000.00$, and with the increased acreage of cane, which high prices naturally brought forth, some $3,000,000$ tons have been produced in I9I6, at a value of over $\$ 250,-$ $\infty, 0,000.00$. In all Latin-American countries, there is no one industry that yields comparatively any thing like this sum for export, and when one considers that the area of Cuba is but 47,000 square miles, and that her population is but $2,500,000$, a clear conception can be formed of the importance of the sugar industry in Cuba.

This industry alone produces an average of $\$ 100.00$ for every man, woman and child in the Republic.

Every acre in cane in Cuba means $\$ 90.00$ to $\$ 100.00$ of wealth, and only about one-fifth of the available land is utilized for sugar growing. Many an estate, during the last year, has yielded a return that more than equals the full value of the property, including land and implements.

Because of the careful method of handling, both by individual owners of plantations, and for the purpose of recording the shares of "Colonas" or tenant farmers, it is possible to definitely publish a table of costs which may be taken as authentic in sugar production: 


\section{ESTIMATE OF THE COST}

Of converting one hundred acres of grass land into sugar cane together with the profits derived from same during a period of two years.

\section{FIRST YEAR}

Cost of plowing, planting and cultivating, first year....\$2,400.00 Cost of cutting 240,000 arrobas (25 pounds) . . . . . $2,400.00$ Cost of hauling to mill .................... $1,200 . \infty$ Incidentals per roo acres. I, 200.00

Yield of cane per 100 acres, 240,000 arrobas.

Amount of sugar received in exchange for said cane at the rate of 6 arrobas for each 100 arrobas of cane, 14,400 arrobas.

$I_{4,400}$ arrobas-360,000 pounds of sugar (a) 4c........\$ $4,400.00$ Expense of planting, cultivating and delivering same,

first year........................... $7,200.00$

Profit per 100 acres.................\$ $7,200.00$

Gross returns on 1,000 acres................. . . 144,000.00

Gross expenses on $\mathrm{I}, 000$ acres ......... . . . . 72,000.00

Net profit on 1,000 acres . .............. $72,000.00$

Net returns per acre............... . $\quad 7^{2.00}$

\section{SECOND YEAR}

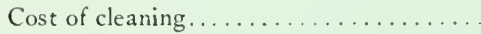

Cost of cutting 100 acres of cane.........

Cost of hauling to mill...............

Incidentals per 100 acres

$1,200.00$

$2,400.00$

$1,200.00$

400.00

$\$ 5,200.00$

Gross returns on I, 000 acres

$1+4,000.00$

Gross expenses on 1,000 acres

$52,000.00$

Net profit on I,000 acres.

$9^{2,000}, 00$

Net returns per acre ................ $\quad 92.00$

In the total profits, drawn at the conclusion, I,, 00 acres are taken since the latter represent the usual size of a colona. 


\section{THE WORLD'S DEMAND FOR SUGAR}

The world's demand for sugar, since I 850 , has been on the gradual increase, and bids fair to continue in even greater ratio than the past.

In the fifties, the consumption for the average American family was two pounds per week.

In the eighties the demand increased to five pounds per week.

In I 900, six pounds per week were consumed by the American family.

And today the consumption runs to between eight and nine pounds.

This applies to the fine sugar purchased in the stores and not the sugar we eat in fruits, potatoes and other foods.

Within two short generations, we have developed a national demand for sugar equivalent to four times our former supply.

No doubt much of this increased consumption is due to the prosperity of the United States, for while our average consumption, per family, in this country is, at the present time, between eight and nine pounds per week, the consumption in Bulgaria, Roumania and Italy amounts to but about one pound per week.

'The world's demand for sugar is universal and depends primarily on the fact that sugar is one of the cheapest foods for the human economy. Prosperity naturally has a marked effect on the purchasing of sweets in which sugar plays such an important part. It is interesting to note the comparison per capita circulation of money and per capita sugar consumption as shown in the following table: 


$\begin{array}{lcc}\text { Per Capita } & \begin{array}{c}\text { Per Capita } \\ \text { Circulation } \\ \text { of Money }\end{array} & \begin{array}{c}\text { Annual Sugar } \\ \text { Consumption }\end{array} \\ \text { United States }(1914) \ldots & \$ 35.18 & 84.29 \text { lbs. } \\ \text { Germany }(1913) \ldots \ldots & 19.29 & +5.13 \mathrm{lbs} . \\ \text { Austria }(1913) \ldots \ldots & 12.08 & 29.17 \mathrm{lbs} . \\ \text { Italy }(1913) \ldots \ldots \ldots & 8.82 & 11.68 \mathrm{lbs} .\end{array}$

England, with a per capita circulation of money less than five-sevenths of our own, has an apparent consumption of 93.37 pounds of sugar per capita, as against our 84.29 pounds.

Considerable of this increase may be accounted for in the immense production of jams, marmalades and other preserves exported ly England. 'Taking this fact into consideration, it is safe to estimate that England's per capita consumption is not as high as our own.

The per capita circulation of money in France is larger than in the United States, but the high cost of sugar and the cheapness of wine makes their sugar consumption considerably less than ours.

Australia has a $\$+7.18$ per capita circulation and consumes one hundred pounds of sugar per capita annually.

This condition is true both as to a comparison between nations and between sections of the same nation, as well as between different periods of a nation's prosperity.

The following table shows comparative consumption of sugar in the United States during three typical periods:

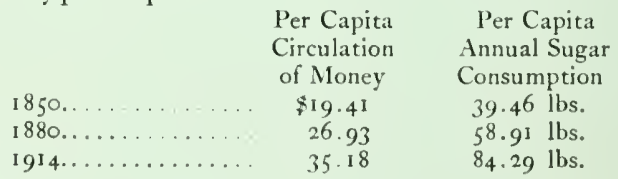


Sugar is one of the best elements for a balanced ration since it has a heat and energy-producing value as great as lean meat, and that the nitrogen retention of proteid food, such as meat, fish, eggs and milk, is increased twenty-five per cent when consumed with sugar. This fact is shown by the following table:

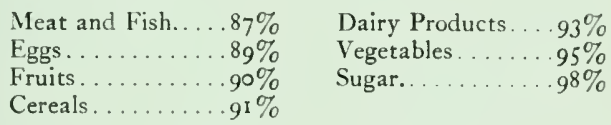

Sugar is no longer considered a luxury, and in proof of this our national candy bill exceeds $\$ 500,000,000.00$ per year.

In 1870 the total production of cane and beet sugar amounted to $2,750,000$ tons.

In 19 I 4 the world's production of sugar had risen to $18,773,486$ tons-an increase of more than 600 per cent.

The sugar production of the world is equivaient to three times the amount of gold mined each year. It is four times as great as the production of petroleum. It is three times as great as the production of tobacco and four times as great as the production of coffee. Six times as great as the production of rubber, and is larger than the entire cotton crop of the world. If the demand for sugar increases during the next fifty years, as it has increased during the past fifteen, we must increase our facilities of production to at least seven times their present capacity.

On the other hand, if the demand should not increase at all, sugar has been established as a world's food beyond any possibility of deterioration. 


\section{SUGAR PRODUCING PLANTS}

There are two classes of sugar in nature, which may, for lucidity, be called single sugars and double sugars. Cane sugar, milk sugar, malt sugar, are some of the double sugars. Grape sugar, and fruit sugar are common single sugars.

Single sugars are produced from double sugars by submitting them either to heat, acid or ferment. The double sugars are of no use as food while they remain in their double state. They cannot be assimilated in the human body for the formation of organic tissue and the production of heat and energy. Only the single sugars are available for this purpose.

Cane sugar has two and one-half times the sweetening power of fruit sugar and more than two and one-half times the sweetening power of grape sugar.

Sugar has been manufactured for centuries from different species of plants by the natives of India. The bamboo is a sugar-producing plant which was utilized by the people of Asia and is supposed to be the first plant from which sugar was extracted. Sugar is manufactured from raisins in practically all of the countries of Southern Europe and Western Asia.

Indian Corn has been used experimentally in the manufacture of sugar, while sorghum, or Chinese cane, with a high sugar content, yields a large syrup crop, but for chemical reasons, little or no sugar.

Sugar has been produced in the United States from watermelons.

But for practical purposes, the commercial sugar of the world is produced from the juice of the cane or the beet. 


\section{CANE VS. BEET}

The Bengalese of India are responsible for the discovery of cane sugar, which discovery was made in the third or fourth century, A. D.

From the fifth century on, this discovery spread into Arabia, Egypt, Spain, Portugal, The Canary Islands, Brazil and Cuba, and thence around the world.

The making of sugar from beets we owe to Napoleon Bonaparte.

In $180_{4}-5$ the business affairs of Europe were in much the same tangle as they are in war times of today.

When Nelson destroyed the French fleet off Trafalgar and England became mistress of the seas, she shut off forever Napoleon's intention of invading the British Isles. At that time Napoleon devised what was known as the "Continental System" which dealt a disastrous blow to the cane sugar industry.

He tried to isolate England by forbidding commercial communication between England and the entire continent of Europe, with the result that the importation of sugar was completely shut off.

Meanwhile the lack of sugar became an important war time problem which required vigorous action. He discovered that sugar could be produced from grapes and from beet roots, and also experimented with other fruits for the production of this national necessity.

After a number of costly experiments had been directed toward the production of grape sugar, with poor results, Napoleon, in I8II, ordered 
32,000 hectares-about 75,000 acres-to be planted with beet roots-distributed over the several provinces-and established four schools in which sugar manufacture was to be taught. Meanwhile he stifled what little competition cane sugar might still be offering, by forbidding all importation from the East and West Indies.

In 18I2, the number of sugar schools was increased and 100,000 hectares were planted247,100 acres - and 324 factories were in operation.

Germany and Austria were quick to see the advantage and led out in the beet sugar industry.

By 1830 the beet sugar industry had reached a high point of production.

The rapid development of the beet sugar industry in Europe had an ill effect on the production of cane sugar for obvious reasons. It was only produced by the most primitive methods and only in sufficient quantities to supply the declining demand.

It was not until the eighties that the cane sugar planter began to realize the natural advantages of cane sugars over those of beet. He lived in tropical style, well up to his income and invested the least possible money in improvements.

In the early 'eighties capital, in moderate amounts, began to be available for sugar planters and the manufacture of cane sugar took on new life.

By 1880 the beet sugar industry had climbed up to a point of production approximately equal to that of cane sugar. The following table illustrates the world's production of sugar, both beet and cane, up to and including $191+$ : 


\begin{tabular}{|c|c|c|c|}
\hline Years & Cane & Beet & Total \\
\hline $1870 \ldots \ldots \ldots \ldots$ & $1,850,000$ & 900,000 & $2,750,000$ \\
\hline $1880 \ldots \ldots \ldots \ldots \ldots$ & $1,860,000$ & $1,810, \infty 00$ & $3,670, \infty 00$ \\
\hline $1890 \ldots \ldots \ldots \ldots \ldots$ & $2,580,000$ & $2,780,000$ & $5,360,000$ \\
\hline $1898 \ldots \ldots \ldots \ldots$ & $2,850,000$ & $4,650,000$ & $7,500,000$ \\
\hline $1900 \ldots \ldots \ldots \ldots \ldots . . . . .$. & $3,056,294$ & $5,590,992$ & $8,647,286$ \\
\hline $1902 \ldots \ldots \ldots \ldots \ldots$ & $4,079,742$ & $6,913,504$ & $10,993,346$ \\
\hline I $903 \ldots \ldots \ldots \ldots \ldots$ & $4,163,941$ & $5,756,720$ & $9,920,66$ I \\
\hline $1904 \ldots \ldots \ldots \ldots \ldots$ & $4,234,203$ & $6,089,468$ & $10,323,631$ \\
\hline I $905 \ldots \ldots \ldots \ldots \ldots$ & $4,594,782$ & $4,918,480$ & $9,513,262$ \\
\hline I906.................. & $6,731,165$ & $7,216,060$ & I $3,947,225$ \\
\hline $1907 \ldots \ldots \ldots \ldots \ldots$. & $7,329,317$ & $7, \mathrm{I} 43,8$ I 8 & $14,473,135$ \\
\hline $1908 \ldots \ldots \ldots \ldots$ & $6,917,663$ & $7,002,474$ & I $3,920,137$ \\
\hline I $909 . . . \ldots \ldots$ & $7,625,639$ & $6,927,875$ & $14,553,514$ \\
\hline 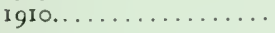 & $8,327,069$ & $6,597,506$ & $14,914,575$ \\
\hline I9II ............ & $8,422,4+7$ & $8,560,346$ & $16,9^{82}, 79^{2}$ \\
\hline I $912 \ldots \ldots \ldots \ldots \ldots$ & $9,006,030$ & $6,820,266$ & I $5,886,296$ \\
\hline I9I $3 \ldots \ldots \ldots \ldots \ldots$ & $9,232,543$ & $8,976,271$ & I $8,208,8 \mathrm{I} 4$ \\
\hline $1914 \ldots \ldots$ & $9,865,016$ & $8,908,470$ & I $8,773,486$ \\
\hline $1915-16 \ldots \ldots \ldots \ldots$ & $10,333, \infty 00$ & $6,306,102$ & $16,639,1 \circ 2$ \\
\hline
\end{tabular}

There is no difference between beet sugar and cane sugar, when refined. The chemical composition, the quality of taste, and the commercial value are identical. It is just a question of which class of sugar can be produced and delivered to the customer at the least cost. 


\section{CUBA A NATURAL CANE COUNTRY}

The climatic conditions required for the profitable production of sugar beet are entirely different from those required for the production of sugarcane. The growing of cane began in the tropics and has never been successfully produced in other sections. It requires a full nine months' growing season of hot days and will not withstand cold weather. It requires both moisture and sunshine and needs an annual rainfall of from fifty to sixty-five inches. In Cuba, where these natural conditions exist, it requires a minimum amount of labor.

Land for the growing of sugar beet is worth from $\$+0.00$ to $\$ 200.00$ per acre for other purposes, while cane grows best in the tropics where land is worth from $\$ 20.00$ to $\$ 50.00$ per acre and where the value of mahogany and cedar generally pays for the cost of clearing.

The beet requires expensive irrigation, cultivation and care, including high priced temperate zone labor, whereas the cane requires no irrigation and practically no cultivation excepting that of harvesting.

In the United States sugar beet produces a profit of from $\$ 15.00$ to $\$ 40.00$ per acre, on land costing from $\$ 40.00$ to $\$ 200.00$ per acre, while the average producer of cane sugar realizes an annual profit of from $\$+0.00$ to $\$ 90.00$ per acre, on land costing from $\$ 20.00$ to $\$ 50.00$ per acre.

There are many other causes which argue in favor of the production of cane sugar as against that of beet. 'The milling season is extremely short in beet producing countries, whereas in Cuba quite a few of the mills grind for as many as nine months during the year, the average being five to six months. 


\section{SUGAR MILLS OF CUBA}

Following is a list of sugar centrales of Cuba at the end of the grinding season 1916:

Name of Central

Asuncion.......... Quiebra Hacha........

Bramales.

El Pilar.

Galope.

Cabanas..............

Artemisa.

S. Juan y Martinez.....

Gerardo..

Bahia Honda

Mercedita

Cabanas....

Orozco

Cabanas...

San Ramon

Amistad . .

Fajardo

Mariel

Guines

Gabriel.

Alquizar.

Gomez Mena........ San Nicolas

Guira............ Guira Melena.

Habana ........... Hoyo Colorado.

Jobo

San Nicolas.

Josefita . .

Los Palos.

Julia, La

Duran.

Loteria.

Mercedita

Jaruco

Melena del Sur

N. S. Carmen....... Jaruco

Nueva Paz.

Los Palos..............

Portugalete

San Jose Lajas

Providencia

Guines.

Rosario.

Aguacate

San Agustin .

Quivican

San Antonio.

Madruga

Toledo...

Marianao

Aguedita .

Arabos.

Alava.

Banagui

Araujo..

Manguito.

Armonia .

Bolondron.

Australia.

Jaguey Grande.

Carolina.

Coliseo

Conchita.

Union de Reyes.

Cuba.

Pedro Betancourt.

Dolores.

Jovellanos.

Dos Rosas .

Cardenas.

Dulce Nombre.

Macagua.
I9I 5

Crop

46,584

27,388

63,959

(Capacity 75,000

Grinds, I9I 7 )

5 , I IO

$9^{2,297}$

42,462

54,820

175,250

39,676

I 7,829

260,550

8,221

39,765

93,563

82,115

186,843

19,597

I 73,648

29,632

85,540

51,136

$1+6,942$

I 86,408

64,408

I 31,500

I 50,346

59,486

210,058

63,000

77,872

.....

72,000

292,66 I

206,820

72,295

43,484

50,295
3,386

$75,4+3$

$3^{6}, 4^{8} 3$

59,600

260,000

64,500

53,096

355,000

34,679

60,125

104,279

$9^{8,576}$

216,777

25,788

205,000

47,039

I 6,639

$73,8 \mathrm{I}_{4}$

I 90,370

$2 \mathrm{I}+, 394$

$9+, 457$

I 54,000

207,702

63,017

266,454

64,000

81,093

28,500

$8 \mathrm{I}, 000$

323,742

200,025

71,804

67,040

6I,II 8 


\begin{tabular}{|c|c|c|c|}
\hline Name of Central & Location & $\begin{array}{r}1915 \\
\text { Crop }\end{array}$ & $\begin{array}{l}1916 \\
\text { Crop }\end{array}$ \\
\hline Elena.... & Ceiba Mocha & I 9,116 & 14,155 \\
\hline Espana. & Artemisal........ & 158,009 & I 61,636 \\
\hline Esperanza..... & Calimete. & 84,145 & 67,600 \\
\hline Feliz.... & Union de Reyes... & 145,438 & $1+1,181$ \\
\hline Flora......... & Macurigues........ & 109,432 & 101,534 \\
\hline Guipuzcoa..... & Hato Nuevo. . . . . & 55,098 & $121,4+6$ \\
\hline Jesus Maria... & Benavides. . . . . . & 42,512 & 67,239 \\
\hline Limones..... & Limonar........ & 84,800 & 120,000 \\
\hline Luisa (Condesa) & Limonar.... & 23,804 & 31,500 \\
\hline Mercedes..... & Guareiras............. & 301,835 & 308,219 \\
\hline
\end{tabular}

Nueva luisa. . . . . Jovellanos.... (Supplying cane to Tinguaro)

Olimpo........... Carlos Rojas.......... (Burned in I914)

Por Fuerza........Calimete.......... 66,085 70,000

Porvenir......... Clara........... 20,000 I9,000

Progreso.......... Contreras.......... I 44,312 I 54,312

Puerto..........Canasi........... $24,143 \quad 23,750$

Reglita..........Perico............ 96,666 100,577

San Cayentano...... Cidra........... 47, 133 45,086

San Ignacio.........Agramonte. . . . . . . . I 20,49 I I 6,071

S. J. Bautista...... Canasi... . . . . . . 20,992 28,199

San Vicente....... Jovellanos.......... 97, $9784 \quad 90,500$

Santa Amalia....... Coliseo........... 44,150 69,132

Sta. Gertrudis...... Banaguises........ 204,687 202,319

Santa Rita........Baro............ 79,120 70,917

Sto. Domingo....... Union de Reyes...... 79,537 79,232

Saratoga..........Limonar........... $54,93^{8} \quad 43,655$

Socorro... . . . . . . . Pedroso . . . . . . . . . 338, 3300 338,069

Soledad.......... Jovellanos ........... I $36,39^{2} \quad$ I 56,625

Tinguaro......... Perico............ 233,615 245,032

Triunfo.......... Limonar........... $21,960 \quad$ I8,600

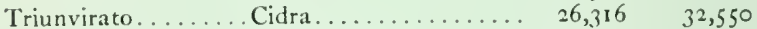

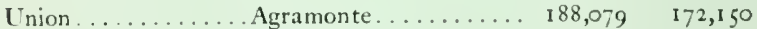

Adela... . . . . . . Remedios........... 83,688 100,074

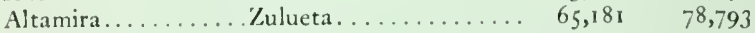

Andreita.......... Cruces ............ 177,344 198,158

Caracas.......... Caracas........... 199,902 I 159,629

Caridad. . . . . . . . Rancho Veloz......... 14,500 38,025

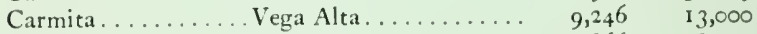

Cieneguita. ........ Abreus . . . . . . . . . 93,866 98,079

Constancia......... Constancia.......... 193,397 172,682

Constancia........ Encrucijada......... 93,862 1 36, 176

Corazon de Jesus. . . . Sagua la Grande...... . $48,057 \quad 65,783$

Covadonga......... Carreno........... 154,603 149,400 


\section{Name of Central}

Location

Dos Hermanas. .

Dos Hermanos. (Acea)

Salvador El. .

$\mathrm{Fe}$.

Fidencia

Hormiguero.

Juragua.

Julia, La

Luisa y Antonia

Lutgardita. .

Macagua.

Manuelita.

Mapos

Maria Antonia.

Maria Victoria.

Narcisa.

Natividad.

Parque Alto

Pastora.

Patricio

Perseverancia.

Portugalete.

Purio

Ramona

Reforma.

Regla.

Resolucion

Resulta.

Rosalia.

Rosa Maria.

San Agustin...

San Agustin.

San Antonio.

San Cristobal.

San Francisco.

San Francisco Asis.

San Isidro..

San Jose.

San Lino...

San Pablc...

San Pedro.

Santa Catalina...
Cruces............. 95,732

34,092

27,990

90,069

$8 \mathrm{I}, \mathrm{1} 86$

219,457

55,129

8,708

161,500

21,530

$5^{6,175}$

37,237

106,852

$54,95^{1}$

.....

90,48 I

I 16,918

22,347

77,354

63,438

100,593

I 92,072

I I I, 3 I I

77,840

52,950

109,724

6,600

$+5,897$

76,622

35,144

6,945

I 39,300

$74,65 \mathrm{I}$

56,308

20,769

82,000

29, I 9 I

41,179

84,631

64,662

36,719

48,315

95,719
I 916

Crop

$9^{8,294}$

$3^{6,4} 19$

32,545

149,780

I 22, I 60

191,404

62,819

10,578

I 75, I 20

6,500

66,249

53,781

$125,79^{8}$

53,426

26,000

96,794

125,000

31,927

79,197

72,133

133,065

130,374 I06,0 11

89,548

69,845

124,848

5,000

$55,15 \mathrm{I}$

104,25 I

48,209

38,354

I 02,147

1 41, 299

67,108

I 8,000

89,604

36,255

44,994

1 24,35 I

87,292

48,536

5 I, 515

104,018 


\begin{tabular}{|c|c|c|}
\hline Name of Central & $\begin{array}{l}1915 \\
\text { Crop }\end{array}$ & $\begin{array}{l}1916 \\
\text { Crop }\end{array}$ \\
\hline Sta. Lutgarda. . . . . Rancho Veloz... . . . . . . & 28,603 & 26,418 \\
\hline Sta. Lutgarda. . . . Mata. . . . . . . . . . & 72,672 & 112,330 \\
\hline Santa Maria........ Ranchuelo........... & $9^{2,945}$ & 101,355 \\
\hline Santa Rosa......... Ranchuelo........... . & 118,849 & I 33,000 \\
\hline Santa Teresa........ Sitiecito............ & 137,703 & 182,921 \\
\hline Stma Trinidad....... Ajuria........ & 63,533 & $6 \mathbf{I}, 289$ \\
\hline Soledad . . . . . . . . . Cienfuegos........... & 126,045 & 142,533 \\
\hline$\ldots \ldots$ Trinidad . . . . . . . . . & 96,727 & 85,877 \\
\hline Tuinicu.......... Tuinicu. .......... & 168,133 & 172,683 \\
\hline ....... Cifuentes....... & 86,879 & II 5,403 \\
\hline Ulacia. . . . . . . . . . Rodrigo. . . . . . . . & $9^{1,77} \mathbf{I}$ & II 4,904 \\
\hline Vega, La... . . . . . . Guayos.......... & 49,216 & $9^{2,168}$ \\
\hline Violeta........... A. de Pasajeros....... & $\ldots$ & 74,000 \\
\hline Vitoria............ Yaguajay...... & $140,35^{8}$ & $163,9^{85}$ \\
\hline ashington........ Hatuey........ & 179,616 & 179,750 \\
\hline ......... Placetas . . . . . . . . . . & IOI, 593 & 122,093 \\
\hline
\end{tabular}

Adelaida.......... Near Moron.......... (Grinds in 1917)

Agramonte......... Florida.............

Camaguey . .........Piedrecitas...........

Cespedes........... Cespedes............

Ciego de Avila....... Ciego de Avila........

Elia............. Guaimaro...........

Florida . . . . . . . Florida.............

Francisco......... Sta. Cruz del Sur.......

Jagueyal........... Ciego de Avila ........

Jatibonico......... Jatibonico...........

Lugareno, E1....... Lugareno............

Moron.

Moron.

Patria.............Moron.

Punta Alegre....... Punta Alegre.........

Senado, El. ........ Senado.............

Stewart.......... Stewart...........

America. . . ....... Maffo...............

Borjita.......... Dos Caminos ........

Boston.............Banes..............

Cape Cruz......... Ensenada de Mora......

Chaparra......... Puerto Madre.........

Confluente........ Guantanamo.........

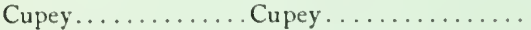

Delicias.

Puerto Padre.

99,286

65,731

….. 30,071

$112,756 \quad 1+1,183$

.... 24,295

74,091

$258,967 \quad 306,500$

$225,705 \quad 233,618$

$275,297 \quad 285,909$

$63,422 \quad 153,791$

$175,5+2 \quad 170,263$

…. $\quad 32,485$

(Grinds in $19: 7$ )

I $31,340 \quad 238,664$

$459,500 \quad 489,054$

$40,123 \quad 70,000$

$45,662 \quad 67,000$

$392,822 * 453,000$

$99,903 \quad 126,515$

$517,010 \quad 613,454$

$52,223 \quad 46,821$

29,362

$311,012 \quad 430,168$

Dos Amigos........Campcchuela....... $65,767 \quad 62,180$

Frmita................................. 56,453

*Estimated, still grinding on August 8, 1916. 


\begin{tabular}{|c|c|c|c|}
\hline Name of Central & Location & $\begin{array}{r}1915 \\
\text { Crop }\end{array}$ & $\begin{array}{l}1916 \\
\text { Crop }\end{array}$ \\
\hline Esperanza.. & Guantanamo. & 80,000 & 86,019 \\
\hline Hatillo... & . Hatillo...... & 72,314 & *80,000 \\
\hline Isabel. . & Guantanamo... & $65,59^{1}$ & $55,5^{8} 3$ \\
\hline Isabel. & Media Luna. & $15^{1,55^{1}}$ & 150,000 \\
\hline Jobabo. & Jobabo.. & 258,909 & 240,388 \\
\hline Los Canos & Guantanamo.... & 61,883 & 72,000 \\
\hline Manati. & Manati............... & 199,354 & 279,000 \\
\hline Monona.. & Guantanamo........... & $\therefore$ & $3,3^{8} 4$ \\
\hline iquero... & Niquero. & $168,5^{8} 5$ & \\
\hline
\end{tabular}

Oriente...........Palma Soriano..... (Grinds in 1917 or 1918 )

Palma...........Palma Soriano........... 70,193

Palmarito.........Palmarito.......... $46,280 \quad 45,200$

Preston...........Preston . . . . . . . . 344,450 * 440,000

Rio Cauto......... Rio Cauto.......... 72,811 68,825

Romelie.......... Guantanamo........ 47,291 28,500

Salvador..........Manzanillo......... 42,446 72,176

San Antonio........ Guantanamo........ 53,336 $\quad{ }^{*} 70,000$

San Manuel. ........ Chaparra...... (Supplying cane to Delecias)

San Miguel......... Guantanamo........ 32,886 28,000

San Ramon........Manzanillo.......... $76,650 \quad 99,437$

Santa Ana........Auza............ 54,966 59,000

Santa Cecilia.......Guantanamo.........6. 60,III 51,354

Santa Lucia... . . . . Santa Lucia.... . . . . . 340,065 *390,000

Santa Maria......... Guantanamo......... $29,687 \quad 34,356$

Sofia............ Bayamo........... $32,444 \quad 35,170$

Soledad........... Guantanamo.......... I1 3,902 104,467

Teresa............ Ceiba Hueca ......... 85,654 92,500

Tranquilidad........ Manzanillo.......... 11,500 15,1 17

Union............ San Luis.......... 51,500 $\quad 63,880$

${ }^{*}$ Estinnated, still grinding on August 8th, I916. 


\section{THE TOBACCO INDUSTRY OF CUBA}

Up to the beginning of the present European War, the tobacco industry of Cuba ranged in importance, second only to that of sugar. The annual value of the crop in normal circumstances is about $\$ 32,000,000.00$.

Since the beginning of hostilities in Europe, and the practical prohibition of tobacco and cigar imports on the part of England and France, and the cancelling of the customary orders, sent in from European countries, export of tóbacco, especially finished cigars, has fallen off in the neighborhood of thirty per cent.

With the restoration of peace, and the resumption of normal conditions, it is reasonable to suppose that tobacco culture will again assume its original importance in the agricultural industries of the Republic; especially so, since Cuba has always been able to produce a grade of tobacco unequalled for its quality in any part of the world.

Tobacco, unlike sugar cane, appears to be dependent for its superior qualities, largely upon particular chemical characteristics of the soil, not easily determined, hence it is that the production is localized. Certain sections are given over entirely to tobacco production and yield a product many times more valuable than the product grown only a few miles distant.

The small selected areas, where the best tobacco is grown, are known as "vegas."

The acknowledged superior tobacco of the world, as to flavor and aroma, is grown within a comparatively short distance from the City of Pinar del Rio, in the Central Western section of 
the province of the same name. This tobacco is known as "Vuelta Abajo" which, together with the wrapper tobacco of the Tumbadero and Guayabal districts, brings the highest prices per acre of any crop in Cuba. It is not unusual for tobacco producers to earn as high as $\$ 500.00$ per acre and often $\$ \mathrm{I}, 000$ per acre is the results of a year's work in this industry.

Tobacco known as "Semi Vuelta" and various other names, is grown throughout the province of Pinar del Rio, especially on the Guane plains, in the valley of Vinales, and in "sumideros" or basins scattered throughout the mountains, as well as in the level country.

Unlike cane, tobacco is heavily fertilized, and owing to the value of the crop, is frequently grown under cheese cloth shade.

As a result of the care necessary for the production of the best leaf, $\$+00.00$ and $\$ 500.00$ per acre is often expended in the production of a crop. The planting is done in the Fall months' and the crop is gathered at the expiration of ninety days, after which follows the process of curing, selecting and marketing. 


\section{CUBA'S COFFEE INDUSTRY}

The growing of coffee offers the home-seeker of moderate means many inducements. Coffee is most successfully grown on rolling lands, or hill sides, where the air is pure and shade grateful, the water fine and drainage perfect.

These conditions are found to perfection on the north coast of the Island.

The culture of coffee is not difficult, and by conforming to a few well known requirements, the industry can be carried on at small expense and with a limited amount of labor.

The coffee plant is an evergreen shrub, with a soft gray bark and dark green laurel-like leaves. The bloom is white pettled star shaped, with yellow centers, and the berries are bright red, growing close to the stem, appearing much as do our cherries in the United States. The bloom is most fragrant.

The shrub is seldom permitted to grow more than ten feet in height and begins to bear three or four years from planting. The berries ripen in about six months from time of blooming and each berry contains two seeds or coffee beansthe surrounding pulp shriveling up as the time approaches for picking. The berries are dried on floors or cloths and are ready for market.

The unpolished, unselected beans, are worth about $\$ 20.00$ per hundred weight, and there is a continual demand at about this price, owing to the fact that Cuban coffee is particularly fine in quality.

In the local market, roasted coffee sells for from $40 \mathrm{C}$ to 5 oc per pound. 
All of the six provinces of Cuba offer exceptional opportunities for the growing of coffee.

Up to the abolition of slavery, in the year I878, the growing of coffee was one of the chief industries of the Island, but with the increased cost of labor, the culture of coffee has rapidly diminished.

Approximately 500 trees are planted to the acre in starting a coffee plantation, and this will vield, under favorable conditions, at the expiration of four years, about one-half pound to the tree-or 250 pounds to the acre, at a value of about $\$ 50.00$ per acre. The sixth year, the trees produce about one pound each, making the acre produce about $\$ 100.00$. Two years later the trees will produce about $\$ 200.00$ per acre, and the tenth year, about $\$ 300.00$ per acre; the twelfth year, $\$ 400.00$ per acre, and succeeding years at least $\$ 500.00$ per acre.

Coffee is a dependable crop, since it can always be stored in bonded warehouses and borrowed against to almost its entire value.

Cuba is importing about $20,000,000$ pounds of coffee per year, with an extensive demand for their own home product.

There is a high protective tariff on imported coffees, which adds materially to the advantage of the coffee grower in Cuba. 


\section{THE CACAO INDUSTRY OF CUBA}

The cultivation of the Cacao Bean, from which chocolate is made, forms an important industry in the agricultural life of Cuba.

It can be grown most successfully in connection with coffee, and while coffee thrives better on hillsides and mountain slopes, where fruit trees and palms furnish the necessary shade, the cacao is adapted to the rich deep soil found in the valleys and ravines that lie between these slopes.

Cacao demands lands that are moist and well drained, with all the humus and natural fertilizing elements possible.

The preparation of land for the growing of cacao includes first the removal of undergrowth and valueless timber, leaving only the royal palms and mangoes, together with a sufficient number of other large trees to warrant plenty of shade, since the cacao plant suffers during the first two or three years from long exposure to the direct rays of the sun. The large trees also serve as a wind-break, which is especially needed in the growing of this product.

Two hundred to three hundred trees are planted to the acre. The young plants spring from the carefully selected beans and evaporation is prevented by mulching with dead leaves.

The variety most commonly grown in Cuba is known as Theobroma, and begins to bear the fourth year, continuing in productivity for half a century.

Each tree will produce from ten to twelve pounds, and the average market price is \$9.00 
per hundred weight, which will yield about $\$ 100.00$ per acre profit.

The method of gathering the crop is as follows:

The pods are removed from the trees in both Spring and Autumn. They are heaped in piles in order to hasten fermentation, which lasts four or five days. After this is completed, the beans are separated from the pods, washed in tanks and dried. The process is simple and rapid, requires no machinery and only a comparatively small amount of labor. 


\section{THE PINEAPPLE INDUSTRY}

Pineapples have been grown in Cuba for export since the beginning of the first intervention and to some extent prior to that time. In point of money value, the pineapple industry ranks high. At the present time most of the pineapples intended for export are grown within fifty miles of the City of Havana. Over a million crates are shipped annually to the United States.

Pineapples may be grown on any rich soil and are considered one of the staple crops of Cuba. The slips, or off-shoots from the parent plant, are set out in long ridges, some four feet apart with intervening spaces averaging a foot. The plants produce fruit within one year of planting and from each original stalk an average of six or eight suckers may be taken for planting in new beds, so that with a very small start the acreage may be easily increased six or eight fold each year.

About eight thousand plants are considered sufficient for an acre of ground, and the cost of these plants is about $\$ 30.00$ per acre. The preparation of the land for pineapples will run considerably more. The returns under favorable conditions will vary from $\$ 100.00$ to $\$ 150.00$ per acre. The average net profits from pineapples grown near Artemisa and Campo Florida, is said to be about $\$ 50.00$ per acre. The high price of sugar since the beginning of the European war has caused much of the former pineapple acreage to be converted into sugar lands.

The profit derived from pineapple culture, as is the case with all fruits and vegetables of a 
perishable nature, depends largely upon the shipping facilities and the localities selected.

A great opportunity is open for the canning of pineapples in Cuba, thus solving the question of transportation and increasing the price of the product, as has been done in the Hawaiian Islands.

The daily freight service between Havana and Key West has been most beneficial to pineapple shippers, and it is stated, on good authority, that a forty per cent increase in price has been made possible by this system. 


\section{THE CULTURE OF CITRUS FRUIT}

Cuba is a natural citrus fruit country, since the sour and bitter orange trees are found wild in almost every forest of the Island.

The lime, growing in its natural state, is found in abundance scattered over the rocky hillsides. Almost everywhere in Cuba are found a few cultivated orange trees, the fruit of which are used for home consumption, but only since American industry took hold in Cuba has citrus fruit been undertaken as a commercial possibility.

Within a comparatively small radius of Havana are many beautiful groves producing excellent revenues.

In the local markets, home grown oranges bring from $\$ 6.00$ to $\$ 15.00$ per thousand.

The gradually increasing demand for this fruit in the United States should prove an incentive to any one interested in this class of horticulture.

There are more than 20,000 acres already planted in citrus fruit in Cuba. The total value of estates in this enterprise is about $\$ 15,000,000.00$. 


\section{MANGOS}

One of the most abundant and delicious fruits in Cuba is the Mango, which grows wild in the forest and will be found along every roadway and in the meadows of the Island. Both tree and fruit resemble the peach in many respects, although the Mango tree grows much larger, frequently attaining a height of fifty or sixty feet. The leaves are long, dark and glossy. The fruit is slightly pear shaped, smooth of skin and varying in tints of yellow, red and russet brown. It is peculiarly refreshing in flavor.

The Mango is an exceedingly delicate fruit and for this reason export shipments have not taken place to any extent.

The fruit comes into bearing in the month of April and continues into September.

The higher qualities grown on grafted trees from India and China sell for from twenty-five to fifty cents each. 


\section{HENEQUEN IN CUBA}

Owing to the chaotic conditions which have prevailed in Mexico, the home of Henequen, for the past three or four years, the manufacture of sisal is today practically at a standstill in that Republic. Many of the large estates have been confiscated by the various political chiefs and thus the owners are seeking investments in other parts of the world. Cuba, lying, as it does, in the same latitude as the Yucatan Peninsula, offers a most exceptional opportunity for the growing of this valuable product.

The Cuban Republic gives absolute protection to the industries of the Island and climate and soil are infinitely better adapted there to the growing of Henequen than is the country in which it first won its fame as a money maker.

Henequen produces a strong fiber only where the soil covers a soft limestone rock, from which the roots apparently secure those elements going to make fiber strong. Cuba has this advantage, and in addition to this, the abundant rainfall gives a more rapid growth so that a Henequen sucker planted in $\mathrm{Cuba}$ will produce, in five years, a yield that could not be attained in less than ten or twelve years in Yucatan.

As a result of the discovery of better Henequen growing conditions in Cuba, the demand tor Henequen lands is rapidly advancing. Within the past year, land suitable for Henequen growing, has advanced from fifty cents to fifteen dollars per acre. Within the past six months, Mexican Henequen growers have purchased approximately 50,000 acres of these lands.

The high prices, and growing demand for the 
fiber throughout the world, makes this industry a most exceptional opportunity on the Island.

The crop is abundantly sure, if planted on the right soil. Lack of rain or long draughts are matters of no importance and the plant will continue to thrive and grow without deterioration in the quality of the fiber.

In Cuba the Henequen plant grows at an average of one inch on each leaf per month.

The Henequen plant has absolutely no enemies. Even fire fails to injure it; cattle will not eat it, and the crop is never stolen as it could never be sold in small quantities.

It is grown on hillsides unsuitable for other cultivation, and the crop may be cut and conveyed to the decortication plants at any season of the year.

The life of the Henequen plant is from fifteen to twenty years, and the average yield in Cuba is about seventy pounds of fiber to 1,000 leaves, while in Yucatan the yield seldom exceeds fifty pounds.

The fiber is indispensable in manufacturing the world's supply of rope, cordage, binding twine, bagging and other rough fabrics.

Estimate of the cost, Growing Henequen and

Producing Sisal, or Fiber from same in the Republic of Cuba.

I00 acres is used as the unit of measure.

Cost of 75,000 plants at $\$ 12.00$ per $1,000 \ldots \ldots \ldots \ldots \$ \$ \ldots 00.00$

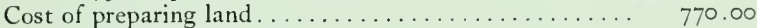

Cost of planting at $\$ 5.00$ per $1,000 \ldots \ldots \ldots \ldots \ldots \ldots \ldots . \ldots \ldots$

Cost of caring for and cultivating during 4 years . . . . . I,350.00

Cost of cutting $5,250,000$ leaves at 500 per $\mathbf{I}, 000 \ldots 2,625.00$

Cost of conveying to mill at $20 \mathrm{C}$ per $\mathrm{I}, 000 \ldots \ldots \ldots \ldots$. . . . . . . . . . . . . . . .

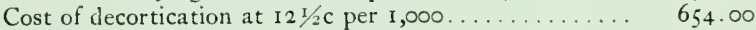

Cost of baling 920 bales at $30 \mathrm{c}$ per bale......... 276.00 
Returns from first cutting 4 years from planting 75,000 plants at 70 pencas (leaves to the plant), 5,250,000 pencas.

$5,250,000$ leaves will yield $70 \mathrm{lbs}$. of fiber to the 1,000 leaves or pencas or $367,500 \mathrm{lbs}$. at $7 \mathrm{c}$ per $\mathrm{lb} \ldots \ldots \ldots 25,725.00$ Cost of production..................... $8,000.00$

Net profit per 100 acres $\$ 17,725.00$ Net profit per acre...

\section{ANNUAL EXPENSE AFTER THE IIRST CUTTING}

Cost of cutting $3,000,000$ pencas ( 40 pencas to the plant)

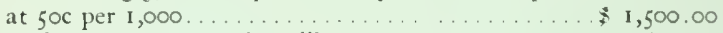

Cost of carting same to the mill at 200 per $1,000 \ldots \ldots 600.00$

Cost of decortication at $12 \frac{1}{2} \mathrm{C}$ per $1,000 \ldots \ldots \ldots \ldots . \quad 375.00$

Cost of baling at 300 per bale ................ 157.00

\section{RETURNS FROM FACH SUCCESSIVE CUTTING AFTER THE FIRST}

75,000 plants, 40 leaves to the plant $-3,000,000$.

$70 \mathrm{lbs}$. of fiber to every I,000 leaves, $210,000 \mathrm{lbs}$. of fiber

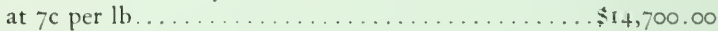

Cost of production...................... 2,632.00

Net profit per 100 acres............... $\$ 12,068.00$

Net profit per acre................. $\quad 120.68$ 


\section{VALUABLE HARDWOOD OF CUBA}

The virgin forests of Cuba abound in valuable hardwoods, such as mahogany, Spanish cedar, rosewood, ebony, lignum-vitae and others. So abundant, in fact, are the hardwoods in these forests, that such valuable woods as mahogany, ebony and lignum-vitae, are used as railroad ties, while in the United States they are sold by the pound.

The constant demand for cedar and mahogany has caused these two woods to be culled out of every forest bordering on the seashore, as far back as the price of the wood on the coast would cover the cost of cutting, trimming, and hauling to deep water. This practice has been carried on for one hundred or more years, and has caused most of the coast land forests to be denuded of the best known woods, large enough for commercial purposes.

With the completion of the V'an Horn railroad, which connects Havana, in the West, with Santiago, in the East, another area of cedar and mahogany was opened up and has been worked quite extensively during the past twelve years.

There are still large amounts of cedar, mahogany and other fine woods scattered throughout the mountain districts, but they are unavailable until more modern methods of transportation are secured, than those furnished by the ox-cart. These sections will remain as an unavailable asset in the country's national wealth until enterprise finds a way of transporting the product.

There are three hundred and sixty-six different woods registered and described in detail in the 
archives of the Department of Agriculture, most of which are absolutely unknown outside of the Republic. Mlost of these are extremely useful, not only for general construction purposes, but as railroad ties that will not rot, handles for tools, implements, etc., ship building, carving, and such other purposes for which hardwoods are always in demand. 


\section{STOCK RAISING IN CUBA}

Cuba, as a whole, offers in abundance, the essential conditions necessary to successful stock raising-nutritious grasses, good drinking water, a climate devoid of extremes in temperature and a steady market always accessible.

There are hundreds of thousands of acres of well watered and well drained lands that possess all of these qualities. Much of the territory formerly devoted to grazing has been recently planted in sugar cane, owing to the high price of sugar, but there still remain large tracts in all of the six provinces, that are not only available for stock raising, but which would produce, under proper management, returns quite as satisfactory as those derived from the sugar industry.

The two grasses best suited for milk or fattening purposes, were imported into Cuba many years ago and are known as the "Parana," brought from the Argentine and best suited to the level lands; and the "Guinea" grass, which was brought from the west coast of Africa and is particularly suited for the mountain sides and crests, up to an altitude of 2,000 feet.

One hundred acres in either one of these grasses, under favorable conditions, will maintain from fifty to seventy head of cattle in good condition throughout the year.

In Cuba there are several varieties of native grasses that spring up in the valleys or whenever the undergrowth is removed from forest lands.

There is every reason to believe that alfalfa will prove as well adapted to Cuba as it has to some parts of the United States, although up to 
the present time but few experiments have been made with it.

On President Menocal's farm, some eight miles from Havana, a splendid stand of this grass has been made and several crops cut the first year. Inocculation of the soil seems to be the only requirement to make this excellent forage thrive on the Island.

The Government experimental station, at Santiago de las Vegas, has succeeded in introducing several new grasses on the heavy clay soils of that neigh borhood.

Water is available in almost any part of the Island, in the rivers and small streams. Wells may he sunk and made to produce excellent water at depths varying from twenty to two hundred feet, and in the mountains, never-failing springs are found in abundance.

The province of Camaguey has always been noted for its fine "Potreros" or meadows since a large part of that middle belt has always been comparatively free from forest and devoted to stock raising.

In Havana and Matanzas provinces, good lands command such prices that they are rather prohibitive for stock raising purposes, but in Pinar del Rio, there are still extensive tracts in the level sections and in the foothills which furnish ideal grazing lands and which, if not absorbed by sugar cane planters will eventually become one of the most successful stock raising districts in the Republic.

These lands may be secured at the present time, in large tracts, at prices ranging from $\$ 20.00$ to $\$ 40.00$ per acre, and should produce a 
vield of from 20 per cent to 40 per cent on the investment.

At the beginning of the War of Independence, in 1895 , over three million head of native cattle were registered in the Island of Cuba. 'The four years of continual struggle between Spain and the people of Cuba almost exterminated this stock. At the beginning of the first intervention cattle were rushed into Cuba from all nearby countries, including Texas, Florida, Venezuela and Mexico. During the past few years quite a number of high grade animals have been introduced for breeding purposes, and the condition of present herds are rapidly improving.

Cuba is quite as well adapted for the raising of horses and mules as any part of the United States.

The abundance of food found throughout the year, the lack of sleet or snow, or cold, wet rains, assure conditions ideal for the growth of young animals up to the point of maturity.

A great many American horses were brought to Cuba by the army of occupation, and it is a notable fact that the losses by disease were less than were experienced in their native country.

The native Cuban horses are of the Arabian stock, introduced in Cuba by the first Spanish conquerors. They are hardy, gentle, good breeders, and of marvelous endurance. When crossed with good Kentucky, Missouri, or Montana stock, they prove excellent service animals.

The breeding of mules, for which there is a great demand in Cuba, would prove a most profitable enterprise, particularly since it will be but a short time when the slow going ox-cart must give way to more rapid methods of transportation in the sugar districts. 


\section{SMALL STOCK RAISING}

\section{HOGS-SHEEP - GOATS}

Cuba, at the present time, is importing approximately ten million dollars' worth of pork and pork products annually, notwithstanding the fact that the Island, owing to especial conditions for raising hogs economically, should not only supply the local demand, but can and will, ultimately be exporting pork products to all of the nearby countries bordering on the Caribbean Sea and the Gulf of Mexico.

The royal palm, which covers many of the hillsides and slopes of the long mountain chains, running parallel with the coast, produces a small nut called "palmiche" that furnishes a neverfailing food which helps the stockman in raising hogs.

The "palmiche," picked up by the animals at the base of the palms, if in sufficient quantity, will keep these animals in fairly good condition throughout the year. Shoats, intended for market, as soon as weaned, should be turned into a field planted with sugar "cane, sweet potatoes, peanuts, yuca, corn, cow peas, "calabaza" or any of those food crops of which hogs are fond and which produce flesh rapidly.

"Palmiche" fed pork is considered a greater delicacy than turkey or chicken. The native or domestic hog of the Island is, as might be expected, a common or scrub product, that, while healthy and prolific, puts on flesh slowly, and is fitted only for fresh pork. This pork, however, with its nutty flavor of the "palmiche" is excellent eating, and when cooked, retails during the holidays at 75 cents per pound. 
The population of the Republic is two and a half millions, increasing at the rate of seventy-five thousand per year. 'The demand for fresh pork in Havana is constant at from $8 \mathrm{I} / 2$ cents to 9 cents per pound, gold, on the hoof. Hams, at wholesale, sell at 26 cents per pound, and other pork products in proportion.

Hogs breed twice a year in Cuba, and the climate, free from extreme heat or cold, enables probably a larger percentage of the young to be brought to maturity, with less care and less risk, than in any section of the United States. Science, today, has rendered it possible to eliminate the danger from contagious diseases to pork, hence it is that the raising of "small stock," especially hogs, under supervision of intelligent management, will prove to be one of the most remunerative industries of the Republic.

SHEEP. Owing to the genial climate, sheep, lacking the necessity for wool with which to retain warmth, very naturally lose it within a comparatively few years. Mutton, however, always commands a good price in the local markets, hence it is that the raising of sheep for food, especially by those small farmers who are close to large markets, will always yield a satisfactory return.

$\mathrm{Up}$ to the present time, little discrimination has been used in introducing those breeds of sheep that are best adapted for the production of mutton. That which they have is usually tender, and of excellent flavor, and if the small farmers would take the trouble to import good rams from desirable breeds in the United States, the raising of mutton, even as a side issue, would 
add greatly to the revenue of those farms that are located near large consuming centers.

GOATS. The Republic of Mexico, for many years past, has derived a very large revenue from the sale of goat skins, most of which were purchased by the New England shoe factories, while the by-products in the form of salted and sun-dried meat, fat, and other materials, always command a market. The recent wars of devastation have practically annihilated all of the great herds of goats in Mexico. During the past three or four years they have been furnishing food to the roving bands of different contestants in that unfortunate country.

If the men interested in the industry would take pains to look into this matter, the advantages which Cuba offers would be manifest. 'The hills and mountain sides of the Republic are clothed to their summits, with underbrush whose tender young shoots furnish excellent feed for animals that browse, and yet the raising of goats has never been considered commercially.

Under the management of men who are familiar with the raising of goats for, their hides, and above mentioned by-products, there is no reason why this industry should not assume importance in Cuba, especially since these animals are invaluable for the purpose of cleaning out undergrowth, economically and effectively.

Detailed information not covered in this book will be supplied upon application to

\section{'THE BANKERS' LOAN \& SECURITIES COMPANY}

NEW ORLEANS : : : : : : : : I.OUISIANA 


Goleta, California STAMPED BELOW.

MAY $26^{\prime} 61$
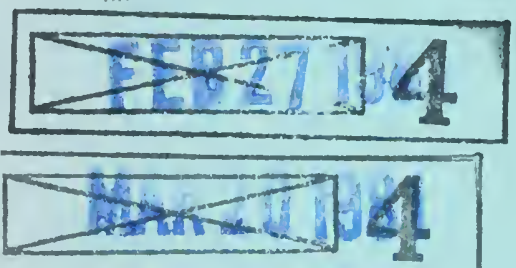


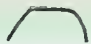

UC SOUTHERN REGIONAL LIBRARY FACILITY

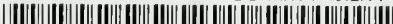

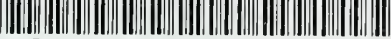
AA $000455086 \quad 9$ 
